\title{
"Stories Like the Light of Stars": Folklore and Narrative Strategies in the Fiction of Éilís Ní Dhuibhne
}

\author{
Giovanna Tallone \\ Independent Scholar
}

Copyright (c) 2017 by Giovanna Tallone. This text may be archived and redistributed both in electronic form and in hard copy, provided that the author and journal are properly cited and no fee is charged for access.

\begin{abstract}
Besides being one of Ireland's best-known and eminent writers, Éilís Ní Dhuibhne is also a professional and recognised folklorist and researcher, whose work covers a diversity of topics and subjects, mostly in the area of the tradition of oral storytelling and urban folklore. Her background in folklore has a relevant impact on her fiction, which is marked by reinvention of folklore patterns and juxtaposition of ancient stories and their contemporary counterpart. The purpose of his essay is to shed light on the impact of folklore and folklore projects on the fiction of Éilís Ní Dhuibhne in terms of in allusions, contents, discourse organization and narrative strategies. The tight link between folklore and storytelling in her writing is analysed taking into account her short stories vis-à-vis her academic work in folklore, focussing on Ní Dhuibhne's awareness of the continuity of traditional narrative in time.
\end{abstract}

Key Words. Ní Dhuibhne, Folklore, Fiction, Storytelling, Scholarship, Creativity.

Resumen. Además de ser una de las escritoras más conocidas y eminentes de Irlanda, Éilís Ní Dhuibhne es también una reconocida folclorista cuyos trabajos de investigación cubren una gran diversidad de temas y materias, fundamentalmente en el area de la tradición oral y el folclore urbano. Esta formación en folclore ha tenido un gran impacto en su ficción, la cual se caracteriza por una reinvención de patrones tomados del folclore y por una yuxtaposición de antiguos relatos y sus correspondientes versiones actuales. El objetivo de este artículo es el de arrojar luz sobre el impacto que tanto el folclore como los proyectos relacionados con el mismo realizados por Ní Dhuibhne han tenido en su ficción, especialmente en todo lo relacionado con alusiones, contenidos, organización del discurso y estrategias narrativas. El estrecho lazo entre folclore y narración de historias en su escritura se analiza aquí poniendo frente a frente sus relatos y su trabajo académico relacionado con el folclore. Se prestará particular atención a la continuación de la narrativa tradicional a lo largo del tiempo tal y como se manifiesta en el caso de Ní Dhuibhne.

Palabras clave. Ní Dhuibhne, folclore, ficción, narración de historias, trabajo académico, creatividad. 
Éilís Ní Dhuibhne is a multifaceted writer, who moves between fiction, drama and scholarship, between English and Irish, and also between different names. She has used the pseudonym of Elizabeth O'Hara for her children's books and for her early and only venture in popular fiction, in the novel Singles (1994); she is known as Éilís Ní Dhuibhne for most of her adult fiction in English and Irish and her plays in the Irish language; and she has used her married name Éilís Ní Dhuibhne-Almquist for most of her scholarly work in folklore (Pelan 15). Besides being one of Ireland's best-known and eminent writers, Ní Dhuibhne is also a professional and recognised folklorist and researcher, whose work covers a diversity of topics and subjects, from the analysis of folklore texts and medieval literary sources, to the presence of folklore in Anglo-Irish literature, to Synge's use of popular material, to the collection and study of urban folklore (A. O'Connor 267-75). Her interest in the origin and diverse forms of storytelling is a fil rouge in her academic work: she found folklore "fascinating" precisely because she has "always been concerned with discovering the secret of storytelling" (Weekes 255), and she admits she turned to writing because she "wanted to know everything there was to know about storytelling" (Kelly 349). As a doctoral student at UCD, she realised that "the roots of literature were not ... in anything that had been written down, but in a still deeper and older layer of narrative that was like a new continent, a magical world [she] had not known it existed" (Ní Dhuibhne, "Why Would" 80). Notably, Ní Dhuibhne’s work as a folklorist has concerned "especially storytelling and the folkloristic genres of folktales and legends" and "the nature of narrative creativity" (A. O'Connor 272). Therefore, her own creative work is constantly and not surprisingly intertwined with folklore in a variety of ways. In an interview with Christine St. Peter she described her use of folklore in her writing as follows:

I allude to old stories. I counterpoint my own stories set in the now, with oral stories, set in the past, or, more accurately, set in the never never or the always always. I feel ... that this enhances my ordinary stories, gives them a depth and a mythic quality... It puts them in a large context - not only an Irish context, since the first thing one learns about oral narrative is its international nature (70).

The purpose of his essay is to shed light on the impact of folklore and folklore projects on the fiction of Éilís Ní Dhuibhne in terms of allusions, contents, discourse organization and narrative strategies in the tight - or maybe inseparable - link between folklore and storytelling in her writing, focussing on her reinvention of folklore patterns and her awareness of the continuity of traditional narrative in time. Ní Dhuibhne's professional stance as a folklorist gives rise to interesting insights into the understanding of the nature of folklore and its strategies and its potential use in modern fiction writing. Such "dynamic interrelationship", as Anne Markey and Ann O'Connor underline in their introduction to Folklore and Modern Irish Writing (5), is productive in many ways in Ní Dhuibhne's writing and is not disjointed from postmodern reflection on the nature of writing itself. Notably, if new adaptations as "responses to the changes in the function of tale" (Uther 9) shed light on the "fantasy of homo narrans", in the case of Ní Dhuibhne the voice and fantasy of mulier narrans rather than vir narrans - so to speak - comes to the fore, thus suggesting implicit issues of gender underlying traditional tales and her own writing. Therefore, Ní Dhuibhne's creative exploitation of folklore provides rich textual developments for analysis at a variety of levels.

In a short piece entitled "Stories Like the Light of Stars", published in RTÉ Sunday Miscellany in 2011, Éilís Ní Dhuibhne recollects her experience as a researcher and folklore collector in Donegal in 1978, "in these days the internet doesn't exist and all research has to be done in libraries or archives. There are no PCs even - I carry a typewriter with me, on the bus" (Ní Dhuibhne, "Stories" 406). Her encounter with the storyteller Joe, namely Joe McCafferty, who "lived out in the wilds in the middle of a bog" (Perry 259) turns into an 
"exhilarating" experience - "I felt I knew how all the collectors must have felt" (Ní Dhuibhne, "Stories" 407) - and develops into a reflection on the nature of stories and storytelling and on creativity:

An oral story, a folk tale, is more fragile than most objects ... It is a complex work of art that is carried in the human memory by the human voice, received by human ears ... What is the right metaphor for the migratory stories? Not butterflies or birds or wild salmon ... I think they are most like lights ... All good stories are flashes of light, stars of knowledge. They are the light in the eyes of a storyteller and of those who love stories, the creative spirit that does not go out as long as people want to be entertained and know how to entertain themselves by weaving words and memories and ideas into interesting patterns. (407-8)

In a second, iterated use of the simile, Ní Dhuibhne states that stories are "immortal, like the light of stars" (408), pointing out their conservative but at the same time innovative nature when they "emerge again" "out of the covers of books and manuscripts" "to inspire writers and artists, and composers, and students and scholars, and new kinds of storyteller" (408). The stylistic choice of listing the possible recipients and users of stories is emphasised by the multiple repetition of the conjunction "and", which provides a sense of continuity in time that is embedded in the collection as well as the preservation and protection of old stories. However, punctuation in the use of commas creates a pause, a moment of stasis and reflection, where the reference to the "new kinds of storyteller" opens the way to all possible uses of folklore material in a creative way.

Éilís Ní Dhuibhne's 2005 essay, “"They Made me Tea and Gave me a Lift Home'; Urban Folklore Collecting 1979-1980", published in Béaloideas, is a reminiscence of her experience as a collector for the pioneering Urban Folklore Project and a reflection on storytelling and storytellers. Interestingly, the paratextual element of the title "They made me tea and gave me a lift home" is more than a summary of her personal experience of the Urban Folklore Project in which people were cooperative to the point that after they "told you great stories", "they gave you a cup of tea and a lift home" (Ní Dhuibhne, "They Made" 83). In a way, this is also a story in embryo: reduced to its smallest elements it recaptures the value of the experience.

Such inclination at creatively combining folklore and storytelling is anticipated in Ní Dhuibhne's debut academic article, "The Brave Storyteller" published in Sinsear in 1980, in which an international folktale collected in April 1978 and September 1979 respectively is entertainingly presented as a "mock trial" (A. O'Connor 268) whose organization goes under headings such as "The Case", "Documentary Evidence", "Discussion of Documents", "External Evidence" and finally "Verdict". Such imaginative frame does not neglect the typical folkloristic analysis and the professional procedure to compare various versions of the tale of "The Brave Tailor" (Ní Dhuibhne, "The Brave" 85), but a humorous and playful tone underlies the whole essay (A. O'Connor 269) especially with the language and register of legal proceedings. Furthermore, the title given by Ní Dhuibhne, "The Brave Storyteller", is a shift of attention from the traditional story to "the famous storyteller, Joe Mac Eachmhartaigh" (Ní Dhuibhne, "The Brave" 84) and to the act of storytelling itself. An unusual choice for a scholarly article, the essay highlights the combination of scientific approach with an imaginative and creative bent. This is consistent with Ní Dhuibhne's writing at large, a personal response to the creative potential embedded in folklore and its use in modern Irish writing. The dynamic quality of folklore itself, always subject to change (Markey and O'Connor 5), creates a fruitful tension in Ní Dhuibhne's narrative, often exploiting folklore and fairy tales to speak productively about the present (St. Peter 70). From 
this point of view, Ní Dhuibhne's narrative exploits what Jacqueline Fulmer calls indirection, namely the presentation of "difficult subject matters to unwilling audiences (1), thus shedding light on "areas of publicly suppressed discourse" (2). Often silenced issues and/or contexts that mark traditional as well as modern Ireland, such as infanticide, child abuse or matters of gender at large are interspersed in Ní Dhuibhne's writing and emerge again to come to new life in her juxtaposition of tradition and modernity. Her postmodern transformation of folktales goes beyond translation or rewriting, and in an article she published in Béaloideas in 1992, she openly stated that "fiction and folklore are free countries" (Ní Dhuibhne-Almquist 149), which reads as a programmatic or strategic stance of her inventive use of folklore in fiction.

Underlying folkloric features are occasionally alluded to and are implicit in the narrative. In her first novel The Bray House, for example, Maggie Byrne, the only survivor of the nuclear disaster that has wiped away Ireland, recalls a changeling in popular tradition; she is "emaciated, apparently bald, with wide crazed eyes staring from greenish skin ... featherlight ... the muscles of her face seemed atrophied" (The Bray 216-17). In her Celtic Tiger novel, Fox, Swallow, Scarecrow, the "woman who looked like a scarecrow" Leo sees waving "at him cheerily" in the crowd at the station (Fox 171-72) is the same scarecrow with "black hair, red rosy cheeks, a big dotty smile" (339) that Kate sees just before the accident in which she is killed, thus recalling a banshee as a traditional messenger of death.

If these references to folklore are embedded in the text, alternatively they can be open and direct, as in the story "Blood and Water", in which the first-person narrator is repelled as a child by the "big splodge of a dirty yellow substance" (114) she sees in the scullery of her aunt's house and thinks is a fungus. Derek Hand points out the "feeling of disconnectedness" (221) between past and present, tradition and modernity as a cornerstone of the story: the narrator needs the authority of academic work at university to discover a meaningful part of local tradition and of her own past: "Years later, when I was taking a course in ethnology at the university, I realised that the stuff was nothing other than butter, daubed on the wall after every churning, for luck" (Ní Dhuibhne, Blood 114).

Folklore is frequently exploited intertextually, thus highlighting the "divergences and continuities between tradition and modernity" (Fogarty xi). "Midwife to the Fairies" is Ní Dhuibhne's first experiment of the use of an intertextual technique as she "counterpoint(s) a modern story with a traditional story" (Moloney 107). "Midwife to the Fairies" is a migratory legend common to different areas in Europe (Mac Cárthaigh 133), known as type ML5070, in which a midwife is taken by the fairies to assist a fairy woman in labour. The interaction between the real world and the world of the fairies undergoes a process of transformation in Ní Dhuibhne's story, in which the juxtaposition between an old legend and its contemporary counterpart, graphically rendered by two different types, creates a "double-levelled structure" (Fogarty $\mathrm{xi}$ ): the contemporary story retells the old one in a realistic $20^{\text {th }}$-century setting, with references to the "Late Late Show" and to place-names in Co. Wicklow. The midwife of the title is called by "a young fellow with black hair, hardly more than eighteen or nineteen" (Ní Dhuibhne 29), an updated variant of the "man standing at the door with a mare" (27) in the original legend. The mare is now "an old Cortina ... a real farmer's car" (29). The journey in "the black night" (29) leads the midwife to a house "buried ... at the side of the road, in a kind of hollow", a coreferent to the "steep hill" of the other world of the fairies (30). The midwife later discovers the baby girl she has helped to be born has been abandoned and has died. Thus Ní Dhuibhne links "an old traditional legend to a contemporary event", in this case newspaper reports of a case of infanticide (St. Peter 68). This practice represents "a very dark side of Irish history and culture" (St. Peter 71) that also appears in The Dancers Dancing, where the baby skulls Orla bumps into in the burn are a visual marker of something still alive in the Ireland of the 1970s: "Skulls. Half a dozen, a dozen, small round white skulls. Tiny skeletons, 
with bones as delicate as the pieces of Airfix model airplanes" (Ní Dhuibhne, The Dancers 202). Ní Dhuibhne's appropriates such issues at a realistic and metaphorical level in order to "focus on specifically female experience" thus "re-writing or re-inventing women's history" (St. Peter 73), which explains her choice of acting as a "historian of the emotional and psychological life of [her] time" (Warwick) in the textual overlapping of past and present.

The interpolation of an old story with a modern one is magnified in the structural organization of Ní Dhuibhne's 1999 collection The Inland Ice. Here the story "The Search for the Lost Husband" is told in parts interspersed among the thirteen stories of the collection. The story rewrites or recasts in different form the legend or fairytale of "The Little White Goat", contained in the section "International Folktales" of the fourth volume of the Field Day Anthology of Irish Writing and introduced by Éilís Ní Dhuibhne as a folklorist and a scholar. In "The Little White Goat", a young girl falls in love and then goes to live with a white goat that turns into a man at night. Every time she has a baby, the goat-husband takes him away threatening the girl never to come back if she cries. In Ní Dhuibhne's adaptation the focus is on the female protagonist who "rejects the tyranny of her shape-changing husband" (Fogarty xi) and in the end takes her life into her own hands. In her comparison and analysis of the original tale and Ní Dhuibhne's story, Elke D'hoker points out both the relevance of the heroine in "The Story of the Lost Husband" and the "unexpected twist" (D'hoker 131) of the ending, as the conventions of fairytales are denied (132) and the girl rejects passionate love in favour of a more realistic husband who offers her "many years" (Ní Dhuibhne, The Inland 262) of happiness (D'hoker 132). In a subversive and metafictional conclusion, the girl declares that she is "tired of all that fairytale stuff" (Ní Dhuibhne, The Inland 262), and in this way Ní Dhuibhne draws attention to the artificial nature of the narrative in a postmodern trend (D'hoker 132), at the same time highlighting the value of female experience and the potential of gender issues embedded in the re-writing of old tales. This experiment in interweaving stories and folktales (Hand 103) also provides thematic unity among stories based on the themes of love, or the search for it, and loss. In the intertextual juxtaposition of ancient stories and their modern counterparts, folklore and story-writing overlap and pretext and aftertext often coexist.

The narrative technique underlying The Inland Ice is also used in the story "The Mermaid Legend" (Mahony 260), from Ní Dhuibhne's 1991 collection Eating Women is not Recommended. As in the case of "The Search for the Lost Husband", the alternating use of a folk version of a legend and of the tale told by a nameless woman in an English pub revolves around zoomorphic transformation, yet, unlike the story of the Little White Goat, with an interesting twist of attention it is the woman who transforms. Here the mermaid of the original legend gets married after a seductive courtship and, as in the old text, she cannot go back to her own form and to the sea as her husband has hidden her cloak: "As soon as Eoin got home he hid the cloak and so she had to stay with him. She became very fond of him and to make a long story short he had her until two children were born, two girls" (Ní Dhuibhne, Eating Women 171; italics in the text). Once again, as in "Midwife to the Fairies", the old legend is printed in italics and fragmented within the contemporary story, which is emphasised by the juxtaposition of the colloquial language of the first-person modern protagonist with the "formal, timeless folk narrative" (Fulmer 112). Iterated references to water elements or water creatures in the first-person narration are a subtext for the mermaid story. For example, the first paragraph closes with a description of the protagonist's life: "Going round in circles I am, like one of them goldfish in that aquarium over there", and the difference between husband and wife is described in animal terms: "We were deep down different, like different species or something. Fish and fowl we were" (Eating Women 169). The unhappy marriage is defined a "sinking ship", as there is "no divorce across the water" the woman takes "the mailboat as fast as my legs can carry me" (171), and in the last paragraph of the story she 
calls herself "a sea girl" (175). The insistence on water imagery reproduces the process of transformation from mermaid into woman and from woman into mermaid. This is a motif that is also explored in the poetry of Eavan Boland, Paula Meehan and Nuala Ni Dhomnhail, and that has been extensively studied by Ní Dhuibhne's husband, the late Bo Almquist, who pointed out that the legend of zoomorphic transformation and marriage between magic sea creatures and a human being "has frequently been used as raw material by literary authors, not least poets" (Almquist 9). Ní Dhuibhne's mermaid figure is a subversive character who counterpoints the original mermaid and whose drinking habits ("One pint of bitter coming right up"; Eating Women 175) are an alternative and playful game with water imagery.

In the story "The Pale Gold of Alaska", Ní Dhuibhne plays again with water creatures, in particular with the selkie legend. A selkie is "a shapeshifter between seal and human form" and selkie stories generally have "dire consequences" (M. O'Connor 153). This is what happens to Sophie whose multiple transformations are related to water. She falls in love with Ned while crossing the Atlantic, she turns from innocent girl to married woman, to lover of the native Indian who makes her feel alive again. If in the early stages of their marriage, while they live in the city, Ned calls her "'Síoda na mBó', which means something like "silken cow" (Ní Dhuibhne, The Pale 5), land animals are replaced by water creatures when they move into the wild. The sealskin her husband gives her has a nearly magic power: "Wrapped in her seal skin, she felt she was a seal ... Naked, bathing in the deep dark pool of the creek, she felt she was a fish. A slippery salmon, fat and juicy, its skin the same colour as the shingle on the banks of the river" (27). The legend of the selkie is interwoven with the story in its tragic conclusion. When the baby Sophie has had from her Indian lover dies, she transforms again and turns into an animal madwoman, walking "around the shanty town, wrapped in her sealskin coat, chanting ... incantations, without cease" (34), an allomorph of the sirens' song.

Also in "Holiday in the Land of Murdered Dreams", water imagery is related to the depth and intensity of love in the urban landscape of Dublin. The variety of water vocabulary in the space of a relative short paragraph leads to the transformation of the protagonist who becomes a mermaid:

Detta felt herself descend into love as into a warm, teeming ocean. Further and further down she went, losing sight of everything that floated on top of this sea, losing all sight and all memory of common dry land. She transformed, girl to fish, girl to mermaid. (Ni Dhuibhne, Midwife 102; emphasis added)

Adaptation, transformation, transposition recur constantly in Ní Dhuibhne's writing. The titles of some of the stories contained in her 1991 collection Eating Women is not Recommended, "The Shapeshifters" and "Transformers in the Sky", reveal how patterns of shapeshifting programmatically underlie her fiction in terms of theme, plot, imagery, metaphor and structuring principle. "Mythically evocative shape-shifting between human and animal occurs in a number of Ní Dhuibhne's stories" (M. O'Connor 155), often in everyday life, as "monstrous women ... make outrageous public scenes, lie, steal, break sexual codes" (St Peter 71), thus resisting or opposing accepted female roles and the status quo. In "Eating women is not recommended" Lennie's blood-stained trousers in a supermarket cause an outrageous reaction in the bystanders, which makes her metaphorically and transgressively shapeshift in front of the store manager: "She was not Lennie anymore, but a tiger dressed in a skirt and tights ... Her yellow eyes flashed fire, her whiskers twitched... (she) growled with as much ferocity as she could muster" (Ní Dhuibhne, Eating Women 138). This anticipates the protagonist's transformation in "Transformers in the Sky", set in another everyday context, a parents' committee. The motif of the shapeshifting body is obliquely introduced in the title, which refers to a toy of the first-person narrator's child, "one of those little transformers all 
the kids are mad about" (143). This textual marker subtly anticipates the zoomorphic transformation at the end of the story in which the protagonist self-consciously transforms into a hare:

I see myself, naked in the middle of my kitchen at home. I'm chewing something, some herb, parsley or something, and I'm transforming. I'm slowly transforming into some sort of animal. A brown animal, furry. A white tail, long legs, long ears. A split lip. It's a rabbit. No. A hare. I've turned into a hare, in my own kitchen. I hop around, timid looking, as if I'm getting my bearings in my new shape. I jump on the table. There's a head of lettuce lying there but I ignore it. Instead I take a flying leap and I'm out through the window, out in the garden.

Out of sight. (148)

The stylistic choice of a new paragraph for the phrase "Out of sight" overtly hints at the protagonist's desire to escape. Her identification with a hare involves the world around her, as the street lights "hop around in front of my eyes so that I can hardly see" (149, emphasis added). Blurred eyesight is reiterated in the "tears that are covering my pupils" (149) in a secret wish to ignore the real world to enter the world of a hare. Ní Dhuibhne makes an oblique reference here to her scholarly work on the Irish legend "The Old Woman as Hare" she had been studying at the time and which was published in the journal Folklore in 1993. The text of the legend is dissimulated in the story in a variant of Ní Dhuibhne's intertextual technique of incorporating folklore material. In her essay she describes the hare as "an animal of prey" ("The Old Woman" 77) in the old legend, following the belief that "certain women were in the habit of transforming themselves into hares for the purpose of stealing milk or butter" (78). She claims that the legend is "an expression of the battle of the sexes" (79) which is replicated in the desire to escape from domesticity embedded in the story, thus implicitly referring to gender issues. The tears in the protagonist's eyes are a textual marker suggesting the power the woman in the story desires but does not have: "Transformed to a wild animal, the woman has a freedom she would not possess in her own shape" (79).

Éilís Ní Dhuibhne's fiction does not only exploit folkloric motifs, text, images or references and allusions related to rural folklore. The city is also relevant for Éilís Ní Dhuibhne, who has lived most of her life in Dublin, from a biographical and an academic point of view. In fact, in the late 1970s she developed an interest in the folklore of urban areas, something that had "been largely neglected by the Irish Folklore Commission, and ... by the Department of Irish Folklore" whose main emphasis had been "almost totally rural oriented" (Mc Clafferty 60). Éilís Ní Dhuibhne was involved "in a pioneering Urban Folklore Project" as a supervisor (A. O'Connor 268), which gave her the opportunity to collect folklore in Dublin and "investigate the modern legends" or "city stories" (Perry 259-60). As she said, they "have an urban setting, but they are told everywhere. They have microwave ovens and cars in them, in some ways they are modern, but of course they're often using very old plots" (Perry 260). They deal with "familiar everyday matters like travel, shopping, pets, babysitting, crime, accident, sex, business, government and so forth" (Brunvand xxvi).

Ní Dhuibhne published a classification of Dublin urban legends in Béaloideas in 1983, pointing out their "international" nature and the local colour of the versions she collected in Dublin (Ní Dhuibhne, "Dublin Modern" 55). She divided them into seven types, ethnocentric legends, legends of violence, legends of theft, legends of revenge, legends about unfortunate or tragic accidents, legends about food, and legends of the supernatural; she provided examples for each type and underlining their oral quality and their characteristic to escape "rigid definition", she made a tentative definition of an urban legend as "a story told as true, of a comic or shocking nature, with a setting which is realistically contemporary" (55). 
Some of the examples are neuter and do not have any specific space referents, others bear typical Irish features, such as The Evening Press or Dunne's Stores, others mention Irish places such as Upton in Co. Cork, Kilkenny, the Naas dual carriageway, Belfast, Warrenpoint; others include places and locations in Co. Dublin, like Portmarnock and Dunne's Stores at Cornelscourt, others specific Dublin places, the Abbey, Dublin Clery's Restaurant, the triangle in Ranelagh. The centrality of the cityscape is not just local flavour per se, as it is consistent with Ní Dhuibhne's concern with Ireland and its changes and with her interest in the "gradual urbanization of Ireland" (Perry 250). Urban legends also provide Ní Dhuibhne the opportunity to consider her perspective on modern Ireland in a wider spectrum. Interestingly, they offer Ni Dhuibhne living and authentic material as a form of continuity in her narrative method and her experimentation in and engagement with intertextuality that characterise her fiction.

In the collection Blood and Water, the story "Fulfilment" represents a variation of $\mathrm{Ni}$ Dhuibhne's technique of juxtaposing an old legend and its modern rewriting, and the concern with space and place-names that opens the story sheds light on the urban and suburban landscape, at the same time indulging in the narratives embedded in place names:

Killiney is the Anglicisation of Cill Inion Leinin, the chapel of the daughter of Léinin. Who she was I do not know. Perhaps a saint like Gobnait of Cill Gobnait. Or a princess like Isolde of Chapelizod. Perhaps she was just the daughter of a butcher, born in Coombe, moving out to Killiney to demonstrate her upward social mobility, like many of those who live there. (Blood 133)

The opening paragraph is a direct reference to "the peculiar nomenclature of the Gaelic language, in which places became associated with individuals, events and topographical features" so that "the land became a kind of narrative in itself" (Smythe 160). However, the first-person narrator deconstructs and plays with the mythic tradition of dindshenchas, the lore of prominent places, which translates places into stories. The playful tone makes fun of the tradition and anticipates the grim humour of the story, in which the protagonist - quite a caricature (Perry 252) - finds her "vocation" in Killiney: "I am a dog killer" (Ní Dhuibhne, Blood 133). The accidental killing of a dog in the neighbourhood gives her the opportunity to solve her money problems. She sells dainty dishes made of dog meat to local restaurants passing it as goat from the North ("Anything could happen in the North, in the view of Dublin burghers", 143) and makes bags and cushions out of their skins which she sells at a street market on Saturdays and Sundays (144).

Interestingly, the story in a way rewrites Ní Dhuibhne's academic article in Béaolideas openly using some scholarly assumptions through nearly direct quotation and exploiting features of type A4 of the ethnocentric legends in the Béaolideas article, that is "A foreign restaurant is discovered to serve dog, cat or Kit-i-Kat. It is closed down" (Ní Dhuibhne, "Dublin Modern" 42; 61). Drifting from job to job (Ni Dhuibhne, Blood 134), the narrator is also "given a job as a folklore collector by a museum in Dublin", an experience which she describes in details (134), also making implicit reference to type F, legends about food: "In the course of my wanderings in Dublin, I had learned that the best-known legend, amounting really to little more than belief, reported the use of dog as food in Chinese restaurants. Alsatian Kung Fu, Sweet and Sour Terrier, Collie Curry, were familiar names to me" (139).

The story is an interesting case of intertextuality as it juxtaposes an urban legend and Ni Dhuibhne's scholarly article in the definition of modern legends, so that Ni Dhuibhne is paraphrasing or rewriting herself in fiction: 
In my work as a folklore collector, I had spent two months investigating a particular genre of tale known professionally as the modern legend. Modern legends are stories which concern strange or horrifying or hilariously amusing events, and circulate as the truth in contemporary society. (139)

And, "professionally", a number of examples follow, not unlike some of the examples provided in the Béaolideas article. The self-referentiality of the text stands out, as the story being told is, actually, an urban legend, which is strange, horrifying, but also hilariously amusing, and the authorial narrating voice is passing it as truth. "Fulfilment" is rooted in the urban landscape as the narrator moves from district to district, ending up in Mountjoy, and the ironic name of the prison ambiguously plays on the story itself.

Éilís Ní Dhuibhne's latest collection of stories, The Shelter of Neighbours (2012), provides an insight into post-Celtic Tiger Ireland with references to the country's recent economic crisis and deterioration in social relationships that characterize the suburban context of the imaginary district of Dunroon. Ní Dhuibhne exploits folklore motifs at a variety of levels, occasionally interlacing them with reflections on writing. Notably, an intertextual rewriting of an urban legend appears in the story "Red-hot Poker", the reworking of a legend of theft, type C2, according to Ní Dhuibhne's classification, which is referred to as "The Robber who was hurt" (Ní Dhuibhne, "Dublin Modern" 57). Briefly, a woman leaves her house on a regular basis, but "one day she breaks her habit" (58) and while watching TV by the fire she realises that someone is trying to break into her house by sawing around the lock on her door. She either hits the hand of the intruder with a hot poker or uses a carving knife. When she goes to her next door neighbour for comfort, he is being treated for a wound on his hand. Soon after the neighbours leave the house and the area.

The paratextual element of the title sheds light on the weapon that is being used and Ní Dhuibhne's story keeps the basic structure unaltered, adding details about the recent death of the husband, the growing friendship and support of the couple next door, Tressa and Denis, who actually turns out to be the robber who is hurt.

The stylistic choice of presenting the crucial incident of the housebreaking attempt in very short paragraphs and sentences made of few words and even of one single word sheds light on the narrator's impression that time is passing very slowly in her moments of anxiety. For example, as soon she is aware of a stranger's presence, the protagonist "plunged the poker into the flames" and then proceeded to a detailed description of her slow gestures:

I let it stay there for a full minute, until it was red hot.

Then I tiptoed to the kitchen door and waited.

Waited.

...

I worried that the poker would cool down. Disastrous. But I didn't dare go back to the fire for fear he'd get in.

Then the piece of wood fell out, onto the floor near my feet. And a hand came through the hole.

...

Down went the poker onto the hand. Hard. (The Shelter 200)

The fragmentation into short paragraphs or sentences is also a coreferent for the changes and fragmentation of the suburban community, anticipated early on in the story by the narrator's observation that "nobody calls in any more these days without phoning. Not where I live 
anyway, out in the suburbs" (191). The reference to emails and Facebook provides a contemporary context to the background of the legend and to the fictional district of Dunroon.

Fragmentation also appears in the repeated use of parenthesis that break the story line giving the effect of pauses in oral storytelling, and occasionally nearly entire paragraphs are in brackets. For example, the nameless protagonist describes her most intimate and private feelings for the first time after her husband's death in brackets:

(I know now what it was. Sympathy. Nobody had really said anything so sympathetic, so encouraging, to me in ages. Nobody had praised me for surviving and putting on a brave face Acknowledgement of the effort I was making was what [Denis] gave me, and it opened the floodgates.) (193)

Éilís Ní Dhuibhne consciously uses two similes early on in the story that act as proleptic catalysts. When the protagonist goes to the bank to withdraw all her money after Frank's death, enquiries begin: "Why did I need so much cash? the girl ... asked, with a smile as warm as a carving knife" (190, emphasis added). The knife as a common object in a kitchen recalls the version Ní Dhuibhne collected in Dublin, where the woman attacks the intruder with "a carving knife that was lying on the draining board" (Ní Dhuibhne, "Dublin Modern" 63) and the adjective "warm" anticipates the red hot poker she will use. Likewise, a couple of paragraphs below, the protagonist describes her feeling of awareness of the death of her husband anticipating the key event of the attempted robbery: "The recollection that he was dead would assault me, like a robber jumping out of a bush and knocking me on the head" (The Shelter 190; emphasis added).

The Shelter of Neighbours (2012) is Ní Dhuibhne's sixth collection of stories, whose title comes from an Irish proverb - "Ar Scath a Chéile a Mhateireann na Daoine", people live in one another's shelter. However, the shelter often becomes an ominous shadow in the urban landscape in a state of crisis after the Celtic Tiger years. The sense of community has deteriorated and robbery and occasionally drug addiction loom in the background. The sense of personal identity is also uncertain, and from this point of view the opening story of the collection, "The man who had no story", highlights doubts about the self, at the same time exploiting traditional forms of narration in a new context.

In "The man who had no story", Ní Dhuibhne creates a continuity between past and present through the mythical names of the protagonists, Finn O'Keeffee, his wife Grainne and their cat Pangur Ban. Finn is a teacher of creative writing, who travels to Kerry for the summer where he hopes to find peace, isolation and concentration to write. All sorts of everyday distractions interfere with his plans, from a sick cat to a broken fridge, so that writing seems to be a nearly impossible achievement, a vain and trivial pursuit. He is aware that paradoxically being a teacher of creative writing has drained him of any creative skill: "He tells people how to do it and encourages them ... Trouble is, he can't give himself a trigger ... Because his imagination is dead" (5-6). The twenty-first-century storyteller who has no stories to tell looks back at his younger self with the awareness that he used to be capable to write "stories effortlessly" (5). His writer's notebook is "full of ... useless items" he may never be able to use (2). The story Finn hears one day on the radio is in a way his own story: in an interplay between tradition and modernity, Ní Dhuibhne juxtaposes the voice of an old seanchai to Finn's abortive attempt to write his work in progress.

Interestingly, the title of Ní Dhuibhne's story reproduces a well-known tale in Irish and Scottish tradition, listed as type 2412 B in Ó Súilleabháin and Christiansen's Types of the Irish Folktale. It exists in a great number of versions (Mac Carthaigh 116) that in spite of divergences in details have in common a man or woman who is unable to entertain his/her host by telling a story. In a pattern of Chinese boxes, the story on the radio recounts Finn's 
own story: Finn has no story to tell, no words to write, like the protagonist of the traditional story, unable to entertain his neighbours with a story until he is taken away by the fairies. Ní Dhuibhne exploits a variation of her usual mode of interlacing a traditional story with a modern one through the pattern of a story-within-a-story, in which parallelisms are clearly evident. Dermot, the man with no story, is carried by the fairies "east and west and north and south" (Ní Dhuibhne, The Shelter 6), he is again "blown east and blown west and north and south" (7), and this allows him to find a story to tell. Finn needs stability to find his story and yet is taken north and south, and back again between Dublin and Kerry, and the story he is looking for is nowhere to be found. The attention to the artist or the writer's figure that develops in Ní Dhuibhne from the stories in The Inland Ice (1997) through the novel Fox, Swallow, Scarecrow to The Shelter of Neighbours, increasingly focuses attention on the act of storytelling and writing, thus providing an original twist to the use of folklore material and indulging on the essence and meaning of writing.

Éilís Ní Dhuibhne imaginatively reworks and experiments with her background in folklore in terms of content, style and narrative strategies through allusions, quotations and creative rewriting. Folklore is alive in her fiction in a variety of ways and forms of narration so that her reinvention of folklore patterns and her awareness of the life and energy of traditional narrative is given and generates new life in contemporary fiction.

\section{Notes}

I would like to dedicate this essay to the memory of my mother, Elsa Fontanella.

\section{Works Cited}

Almquist, Bo. “Of Mermaids and Marriages. Seamus Heaney's 'Maighdean Mara' and Nuala Ní Dhomnaill's 'An Mhaighdean Mhara' in the Light of Folk Tradition. Béaloideas 58 (1990): 1-74.

Brunvand, Jan Harold. Encyclopedia of Urban Legends. Updated and Expanded Edition. Santa Barbara, Denver, Oxford: ABC-CLIO, 2012.

D'hoker, Elke. "The Postmodern Folktales of Éilís Ní Dhuibhne". ABEI Journal 6 (2004): 129-39.

Fogarty, Anne. "Preface". Éilís Ní Dhuibhne. Midwife to the Fairies. New and Selected Stories, by Éilís Ní Dhuibhne. Cork: Attic Press, 2003. ix-Xv.

Fulmer, Jacqueline. Folk Women and Indirection in Morrison, Ni Dhuibhne, Hurston and Lavin. Burlington, Aldershot: Ashgate, 2007.

Hand, Derek. "Éilís Ní Dhuibhne". The UCD Aesthetic: Celebrating 150 Years of UCD Writers. Ed. Anthony Roche. Dublin: New Island Press, 2005. 218-228.

Kelly, Shirley. "Fiction is to Take You to Places You Didn't Know". Books Ireland 236 (December 2000): 349.

Mac Carthaigh, Críostóir. "Midwife to the Fairies (ML 5070). The Irish Variants in their Scottish and Scandinavian Perspective". Béaloideas 59 (1991): 133-43.

McClafferty, George. "City Folk". Sinsear. The Folklore Journal 2 (1980): 60-63.

Mahony, Christina Hunt. Contemporary Irish Literature. Transforming Tradition. Basingstoke, London: Macmillan, 1998.

Markey, Anne and Ann O'Connor. Folklore and Modern Irish Writing. Sallis, Co. Kildare: Irish Academic Press, 2014.

Moloney, Catriona and Helen Thompson. Irish Women Speak Out. Voices from the Field, Syracuse: Syracuse University Press, 2003. 
Ní Dhuibhne, Éilís. “The Brave Storyteller”. Sinsear. The Folklore Journal 2 (1980): 84-91.

—. "Dublin Modern Legends: An Intermediate Type list and Examples". Béaloideas 50 (1983): 55-70.

- Blood and Water. Dublin: Attic Press, 1988.

- Eating Women is Not Recommended. Dublin: Attic Press, 1991.

—. "The Old Woman as Hare': Structure and Meaning in an Irish Legend". Folklore. 104 (1993): 77-85.

- The Inland Ice. Belfast: The Blackstaff Press, 1997.

- The Dancers Dancing. Belfast: The Blackstaff Press, 1999.

- The Pale Gold of Alaska. London: Review, 2001 (2000).

—. "Why Would Anyone Write in Irish?". "Who Needs Irish": Reflections on the Importance of the Irish Language Today. Ed. Ciarán Mac Murchaidh. Dublin: Veritas Publications, 2004. 70-82.

_. " "They Made me Tea and Gave me a Lift Home'; Urban Folklore Collecting 19791980". Béaloideas 73 (2005): 63-84.

- Fox, Swallow, Scarecrow. Belfast: The Blackstaff Press, 2007.

—. "Stories Like the Light of Stars". RTÉ Sunday Miscellany. Ed. Clíodhna Ní Anluain. Dublin: New Island, 2011. 406-408.

- The Shelter of Neighbours. Belfast: The Blackstaff Press, 2012.

Ní Dhuibhne-Almquist, Éilís. "Legends of the Supernatural in Anglo-Irish Literature". Béaloideas 60-61 (1992-93): 145-50.

O’Connor, Anne. "With Her Whole Heart: Éilís Ní Dhuibhne and Irish Folklore”. Éilís Ní Dhuibhne. Perspectives. Ed. Rebecca Pelan. Galway: Arlen House, 2009. 263-84.

O'Connor, Maureen. The Female and the Species. The Animal in Irish Women's Writing. Oxford, Bern: Peter Lang, 2010.

Pelan, Rebecca. "Introduction". Éilís Ní Dhuibhne. Perspectives. Ed. Rebecca Pelan. Galway: Arlen House, 2009. 9-28.

Perry, Donna. "Éilís Ní Dhuibhne". Backtalk. Women Writers Speak Out. New Brunswick, New Jersey: Rutgers University Press, 1993. 245-60.

Smythe, Gerry. The Novel and the Nation. Studies in the New Irish Fiction. London and Chicago: Pluto Pres, 1997.

St Peter, Christine. 2006. "Negotiating the Boundaries. An interview with Éilís Ní Dhuibhne". The Canadian Journal of Irish Studies. 32. 1 (Spring 2006): 68-75.

Uther, Hans-Jörg. The Types of International Folktales. A Classification and Bibliography. Helsinki: Academia Scientiarum Fennica, 2004.

Warwick, Nicola. “One Woman's Writing Retreat”. E-mail interview with Éilís Ní Dhuibhne, 2001. 3 May 2010. www.prairedom.com/font_porch/visiting_authors/dhuibhne.html.

Weekes, Ann Owen. Unveiling Treasures. The Attic Guide to the Published Works of Irish Women Literary Writers. Dublin: Attic Press, 1993.

Received: 19 February $2017 \quad$ Revised version accepted: 11 May 2017

Giovanna Tallone is a graduate in Modern Languages from Università Cattolica del Sacro Cuore, Milan, and holds a $\mathrm{PhD}$ in English Studies from the University of Florence. An independent researcher and EFL teacher in secondary school, she has presented papers and published essays and critical reviews on Éilís Ní Dhuibhne, Mary O’Donnell, Mary Lavin, Clare Boylan, Lady Augusta Gregory, Brian Friel, Dermot Bolger and James Stephens. Her 
main research interests include Irish women writers, contemporary Irish drama, and the remakes of Old Irish legends.

giovanna.tallone@alice.it 